\title{
Exposure to tremolite asbestos and respiratory health in Swedish dolomite workers
}

\author{
A I Seldén, N P Berg, E A L Lundgren, G Hillerdal, N-G Wik, C-G Ohlson, L S Bodin
}

Department of Occupational and Environmental Medicine, Örebro Medical Centre Hospital, SE-701 85 Örebro, Sweden A I Seldén N P Berg C-G Ohlson L S Bodin

Workplace Air, National Institute for Working Life, SE-112 79 Stockholm, Sweden E A L Lundgren

Department of Medical Sciences, Respiratory Medicine and Allergology, University Hospital, SE-751 85 Uppsala, Sweden

G Hillerdal

Division of Bedrock Geology, Geological Survey of Sweden, Kiliansgatan 10, SE-223 50 Lund, Sweden

N-G Wik

Correspondence to: Dr A Seldén anders.selden@orebroll.se

Accepted 18 May 2001

\begin{abstract}
Objectives-Deposits of carbonate rock like limestone and dolomite may contain tremolite asbestos. This study assessed the exposure to tremolite asbestos and the respiratory health of Swedish dolomite workers.

Methods-95\% of 137 eligible workers at two dolomite producing companies completed a self administered questionnaire that included questions on respiratory symptoms and were examined with spirometry as well as chest radiography. Total exposure to dust was gravimetrically measured and the tremolite asbestos content of the dust was assessed with polarisation and phase contrast microscopy.

Results-Dolomite dust concentrations were moderate (median $2.8 \mathrm{mg} / \mathrm{m}^{3}$ ) and tremolite asbestos concentrations were generally below the limit of detection $(<0.03$ fibres $/ \mathrm{ml})$. Somewhat higher values, around 0.1 fibres $/ \mathrm{ml}$, were obtained in manual stone sorting and bagging. Respiratory symptoms suggestive of chronic bronchitis were more related to smoking than to estimates of individual exposure to dust. The mean vital capacity was 0.21 lower than expected after adjustment for sex, age, height, and smoking but the decline in lung function was not associated with current or cumulative exposure to dust in a clear cut way. Two definite cases of pleural plaques and one possible case of simple pneumoconiosis were noted, but the plaques could not be attributed exclusively to exposure to tremolite asbestos.

Conclusions-Dolomite mining and milling may indeed entail low levels of exposure to tremolite asbestos, but this exposure was not a strong determinant of respiratory symptoms, lung function, or pneumoconiosis in exposed Swedish workers. This was true also for dolomite dust. The hazards of exposure to tremolite asbestos may vary across deposits, however, and additional studies at other sites of carbonate rock exploitation are warranted.

(Occup Environ Med 2001;58:670-677)
\end{abstract}

Keywords: asbestos tremolite; dolomite; lung function

Limestone and dolomite are examples of sedimentary rock which are also recognised as carbonate rocks. Limestone contains more than $50 \%$ of the mineral calcite (calcium carbonate) but if the carbonate rock is rich in magnesia a double salt with carbon dioxide and calcium oxide called dolomite $\left((\mathrm{CaMg}) \mathrm{CO}_{3}\right)$ is often formed. The ensuing bedrock is called dolomitic limestone or dolomite. Carbonate rocks are used as industrial minerals in various applications - for example, in the production of mineral wool, iron and steel, in the paper industry, as a filler in house and road construction materials, in plastics, paints, and adhesives, and in agriculture.

Carbonate rocks with a low content of silica have been considered to be virtually harmless. ${ }^{1}$ A few cases of pneumoconiosis in Finnish limestone mines have been attributed to silicate impurities or quartz in the rock, ${ }^{2}$ but only one case of pneumoconiosis associated with dolomite has been properly reported in the international literature. ${ }^{3}$ Exposure measurements in Finnish limestone and dolomite mines showed varying concentrations of quartz and mineral fibres with tremolite and wollastonite as the most abundant fibrous silicates. Forty per cent of the tremolite particles were perfect fibres, of tremolite asbestos, whereas the remaining fraction was classified as either fibrous cleavage fragments or cleavage fragments. At one dolomite mine the mean airborne concentration of perfect tremolite fibres was over 0.1 fibres $/ \mathrm{ml}^{2}$

Clusters of pleural mesothelioma and other health effects related to asbestos have been associated with background exposure to tremolite asbestos in various environmental settings, notably from locally produced whitewash made from sedimentary rock. ${ }^{4-10}$ Similar associations have been found in occupationally exposed groups - for example, in vermiculite workers in the United States and Canadian chrysotile workers. ${ }^{11-14}$

Tremolite asbestos occurring as a natural component of the bedrock has been associated with pleural plaques in Swedish iron miners without other exposure to asbestos, ${ }^{15}$ and sporadic cases of diffuse pleural thickening or pleural plaques have been attributed to tremolite asbestos from products containing milled dolomite. ${ }^{16} 17$

In the area of Bergslagen in central Sweden the bedrock contains metamorphosed sedimentary and volcanic rocks created some 1900 million years ago. Serpentine and amphiboles are common impurities in Swedish carbonate rocks but chlorite, mica, and talc are also found. Occurring in both orthorhombic and monoclinic systems, the amphibole group comprises several minerals closely related in crystallographic and other physical properties as well as in chemical composition. Among the 


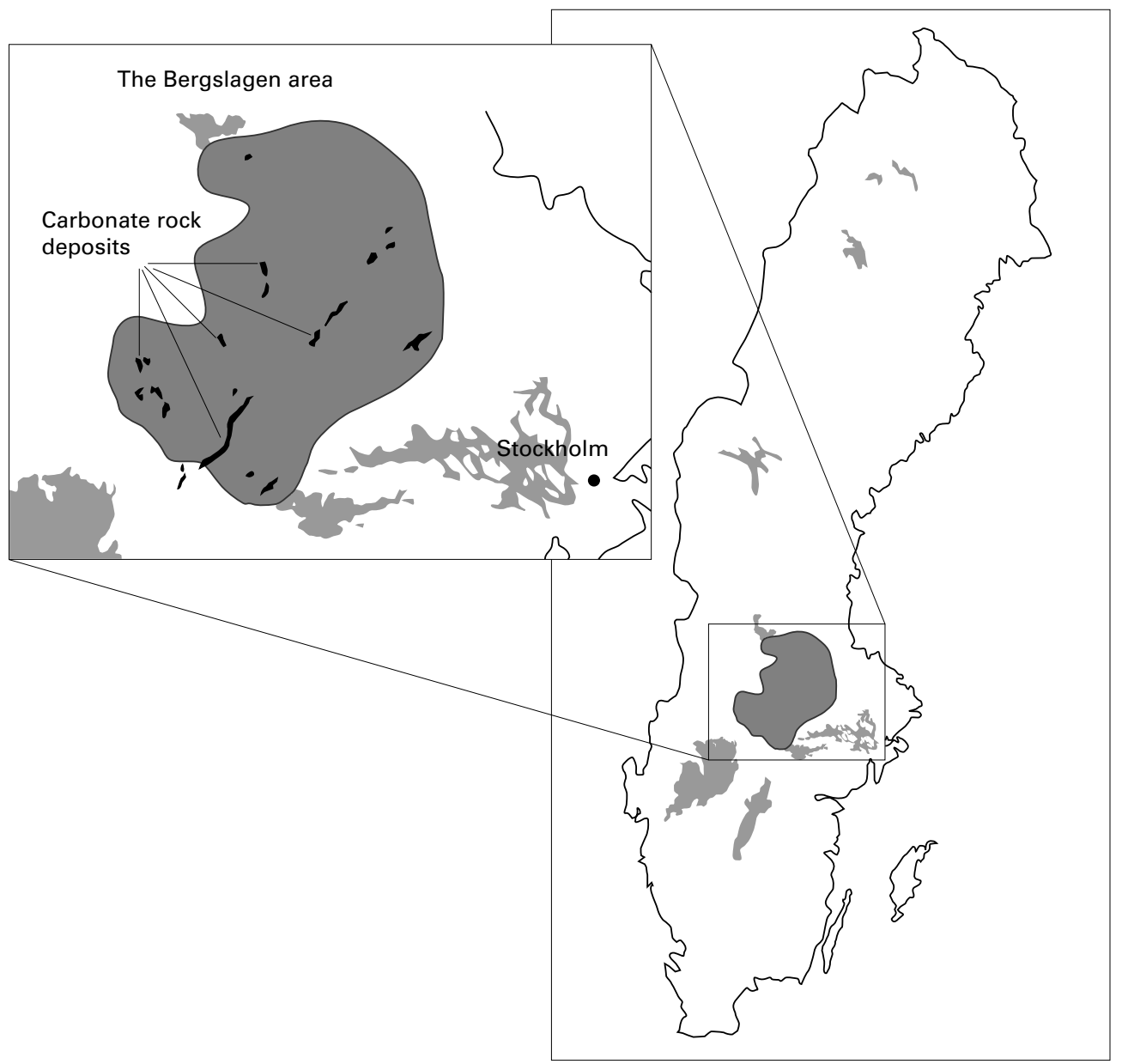

Figure 1 Map of Sweden with details of carbonate rock deposits (in black) in the Bergslagen area.

amphiboles, created by metamorphic processes, the tremolite-actinolite series belonging to the monoclinic system dominate. The minerals usually form aggregates of long prismatic crystals, sometimes fibrous and asbestiform and recognised as tremolite asbestos as opposed to non-asbestiform tremolite cleavage fragments. The colour of tremolite is white, turning green with increasing iron content.

The respiratory health of Swedish dolomite workers has previously not been systematically investigated and the aim of this study was to conduct such a survey with special emphasis on the recent findings of occupational exposure to tremolite asbestos.

\section{Material and methods}

COMPANIES

The study was conducted at two dolomite mines with adherent production facilities, here called company A and company B, located in the Bergslagen area of central Sweden (fig 1). Their combined produce was estimated to constitute some $50 \%$ of the annual domestic dolomite production (about 700000 metric tonnes). The mineralogical, geological, and chemical characteristics of the two sites were similar (tables 1 and 2). Attempts to increase the statistical power of the study failed when the two additional and relevant carbonate rock
Table 1 Mineralogical composition ( $\%$ by weight) of carbonate rock samples from company $A$ and company $B$

\begin{tabular}{llll}
\hline \multirow{3}{*}{ Mineral } & & \multicolumn{2}{c}{ Company B } \\
\cline { 3 - 4 } \cline { 3 - 4 } & Company $A$ & Sample 1 & Sample 2 \\
\hline Dolomite & 93 & 91 & 92 \\
Calcite & 3 & 6 & 3 \\
Amphibole & 4 & 2 & 4 \\
Mica & Trace & ND $^{\star}$ & Trace \\
Talc & Trace & ND & Trace \\
Quartz & ND & Trace & ND \\
Chlorite & ND & ND & Trace \\
Total & 100 & 99 & 99 \\
\hline
\end{tabular}

^Not detected.

producing companies in the Bergslagen area declined to participate.

Preceded by small scale quarrying by local farmers, industrial dolomite mining at company A started in 1918. The current production facilities, including the underground mine, dated from the 1960s and contained departments for stone sorting, crushing, grinding, mixing, and packing. Over the years, various additives had been used to improve the quality of local products among which asbestos was of particular interest for the present study. Circumstantial information indicated that some 40 tonnes of asbestos (possibly antophyllite) were added as a fire retardant to selected qualities in the 1960s and early 1970s. The use of asbestos was thought to have ended when national restrictions were introduced, 1976 at 
Table 2 Chemical composition (\% by weight) of carbonate rock (dolomite) samples from company $A$ and company $B$

\begin{tabular}{|c|c|c|c|}
\hline \multirow[b]{2}{*}{ Compound } & \multirow{2}{*}{$\begin{array}{l}\text { Company } A \\
\text { (mixed sample) }\end{array}$} & \multicolumn{2}{|c|}{ Company B } \\
\hline & & Sample 1 & Sample 2 \\
\hline $\mathrm{SiO}_{2}$ & 1.87 & 0.85 & 1.94 \\
\hline $\mathrm{Al}_{2} \mathrm{O}_{3}$ & 0.22 & 0.33 & 0.36 \\
\hline $\mathrm{TiO}_{2}$ & $<0.01$ & $<0.01$ & $<0.01$ \\
\hline $\mathrm{Fe}_{2} \mathrm{O}_{3}$ tot & 0.49 & 0.78 & 0.53 \\
\hline $\mathrm{MnO}$ & 0.07 & 0.12 & 0.07 \\
\hline $\mathrm{CaO}$ & 30.2 & 30.3 & 30.1 \\
\hline $\mathrm{MgO}$ & 20.4 & 20.7 & 20.9 \\
\hline $\mathrm{K}_{2} \mathrm{O}$ & 0.03 & 0.02 & 0.04 \\
\hline $\mathrm{Na}_{2} \mathrm{O}$ & 0.02 & 0.02 & 0.02 \\
\hline $\mathrm{P}_{2} \mathrm{O}_{5}$ & 0.01 & $<0.01$ & $<0.01$ \\
\hline $\mathrm{CO}_{2}$ & 45.7 & 46.0 & 44.8 \\
\hline S & $<0.01$ & $<0.01$ & $<0.01$ \\
\hline Total & 99.0 & 99.1 & 98.8 \\
\hline
\end{tabular}

the latest, but no details on this issue were available in company records.

At company B open pit limestone mining, followed by underground mining, started in the early 20th century but this production almost ended in 1970. Open pit dolomite quarrying was started in the 1920 s and subsequently became the main mineral. The carbonate stones were locally sorted, refined by crushing and grinding, and sometimes mixed with other ingredients for various industrial products and consumer goods. The history of asbestos use at company $\mathrm{B}$ was thought to be largely congruent with company $\mathrm{A}$, but no quantitative or qualitative information was available.

SUBJECTS AND RESPIRATORY HEALTH SURVEY In late 1996 all blue collar workers and foremen at companies A and B were invited to participate in a respiratory health survey including a questionnaire, spirometry, and a chest radiograph. Out of a total workforce of 137 subjects, 130 agreed to participate. The participants were 20-63 years old (median 43 years) and $12 \%$ were female (for further demographic characteristics of the study population (table 3)).

Table 3 Some demographic and exposure characteristics of the study group

\begin{tabular}{|c|c|c|c|}
\hline Characteristic & $\begin{array}{l}\text { Company } A \\
n(\%)\end{array}$ & $\begin{array}{l}\text { Company B } \\
n(\%)\end{array}$ & $\begin{array}{l}\text { Total } \\
n(\%)\end{array}$ \\
\hline \multicolumn{4}{|l|}{ Sex: } \\
\hline Men & $77(87)$ & $37(90)$ & $114(88)$ \\
\hline Women & $12(13)$ & $4(10)$ & $16(12)$ \\
\hline \multicolumn{4}{|l|}{ Age (y): } \\
\hline $20-29$ & $14(16)$ & $7(17)$ & $21(16)$ \\
\hline $30-39$ & $27(30)$ & $8(20)$ & $35(27)$ \\
\hline $40-49$ & $21(24)$ & $13(32)$ & $34(26)$ \\
\hline $50-59$ & $24(27)$ & $11(27)$ & $35(27)$ \\
\hline$\geqslant 60$ & $3(3)$ & $2(5)$ & $5(4)$ \\
\hline \multicolumn{4}{|l|}{ Body mass index: ${ }^{\star}$} \\
\hline $18.5-24.9$ (normal weight) & $29(33)$ & $12(29)$ & $41(31)$ \\
\hline $25.0-29.9$ (grade 1 overweight) & $45(51)$ & $17(41)$ & $62(48)$ \\
\hline $30.0-34.9$ (grade 2 overweight) & $11(12)$ & $8(20)$ & $19(15)$ \\
\hline $35.0-39.9$ (grade 2 overweight) & $4(4)$ & $4(10)$ & $8(6)$ \\
\hline \multicolumn{4}{|l|}{ Smoking habits: } \\
\hline Non-smokers & $40(45)$ & $19(46)$ & $59(45)$ \\
\hline Ex-smokers & $27(30)$ & $13(32)$ & $40(31)$ \\
\hline Smokers & $22(25)$ & $9(22)$ & $31(24)$ \\
\hline \multicolumn{4}{|l|}{ Duration of employment (y): } \\
\hline-5 & $10(11)$ & $6(15)$ & $16(12)$ \\
\hline $5-9$ & $29(33)$ & $12(29)$ & $41(32)$ \\
\hline $10-14$ & $20(22)$ & $6(15)$ & $26(20)$ \\
\hline $15-19$ & $8(9)$ & $5(12)$ & $13(10)$ \\
\hline $20-29$ & $17(19)$ & $9(22)$ & $26(20)$ \\
\hline$\geqslant 30$ & $5(6)$ & $3(7)$ & $8(6)$ \\
\hline Total & 89 & 41 & 130 \\
\hline
\end{tabular}

${ }^{\star}$ Classification according to the World Health Organisation. ${ }^{18}$
The questionnaire covered items of general health and medication, tobacco habits, and environmental exposure to smoke, an occupational history including a subjective dust assessment as well as use of a respirator and previous exposure to asbestos. The prevalence of respiratory symptoms was assessed with a 14 item questionnaire designed for use in populations occupationally exposed to dust. This questionnaire contains eight questions from the British Medical Research Council (MRC) questionnaire ${ }^{19}$ (three items referring to cough, three to phlegm, and two to dyspnoea) and six additional questions referring to simple bronchitis with or without phlegm or to obstructive symptoms. The 14 item questionnaire and the MRC questionnaire had previously been validated against respiratory function tests and airways disorders classified by lung specialists in a study of 295 asbestos cement workers. ${ }^{2021}$ This validation suggested an optimal cut off value for sensitivity and specificity at any three or more symptoms - that is, the sum of positive responses in the questionnaire without weighting. No reference data from groups unexposed to respiratory irritants were available, but data from two groups of welders (unpublished) and swine producers ${ }^{22}$ were used for comparison.

Lung function was investigated according to standards set by the American Thoracic Society ${ }^{23}$ using a dry wedge spirometer (Vitalograph, Buckingham, UK). Observed best values for vital capacity (VC) and forced expiratory volume in 1 second $\left(\mathrm{FEV}_{1}\right)$, adjusted for body temperature and pressure saturated with water vapour, were compared with predicted values generated from Hedenström et $a l^{4}$ for women and Hedenström et al for men. ${ }^{25}$ The reference data were adjusted for sex, age, body height, and smoking (smokingyears). Standardised measurements of height and weight were obtained and body mass index (BMI) was calculated.

Standard chest radiographs were obtained at hospitals serving the areas of interest but examinations conducted within about 1 year were not repeated. Antero-posterior films were read independently by two experienced observers, one senior radiologist and one lung physician, with the 1980 International Labour Office (ILO) guidelines as reference. ${ }^{26}$

\section{EXPOSURE ASSESSMENT}

The medical examinations were supplemented with exposure to dust measurements as well as a review of historical exposure data.

DUST MEASUREMENTS

The methods of production had remained fairly stable for decades at both companies but systematic investigations of the exposure to dust had not been undertaken. Beginning in the late 1960s, sporadic dust samples had been collected from various departments as either area or exposure measurements. Some measurements concerned total dust only whereas others were focused on respirable silica, respirable dust, or any combination thereof. Fortunately, the methods of dust sampling were similar over the observation period, and since 
1975 most samples had been analysed at the same laboratory. These circumstances were considered sufficient to allow comparisons over time. Available protocols were scrutinised for overall quality, discarded if necessary, and the exposure measurements (personal dust sampling) were summarised.

Occasional attempts to measure exposure to asbestos had been made in earlier decades, but the historical methods for fibre analysis did not differentiate between asbestos and other fibres. Hence, the validity of these data was considered low for an assessment of previous exposure to tremolite asbestos and they were discarded.

As part of the current investigation, air samples were collected from both companies and analysed for total dust and tremolite asbestos. The aim of the sampling strategy was to supplement the historical measurements and to collect information from job tasks previously not studied. The dust sampling method conformed to the corresponding United States standard ${ }^{27}$ and had been used since the 1960s. In short, full shift (5-8 hours) personal air samples were collected with calibrated pumps with an air flow rate of $21 / \mathrm{min}$ and conditioned $25 \mathrm{~mm}$ diameter cellulose acetate filters (pore size $0.8 \mu \mathrm{m}$ ) mounted in open cassettes. The dust content was gravimetrically determined.

The exposure to tremolite asbestos was assessed with stationary sampling equipment with pure cellulose nitrate membrane filters (diameter $25 \mathrm{~mm}$, pore size $0.8 \mu \mathrm{m}$ ). The measurements were collected over 30,60 , or 90 minutes to ensure suitable amounts of dust for the fibre analyses.

For each subject in the study, estimates of both the current and the overall mean exposure to dolomite dust (covering their entire duration of dolomite work) were calculated. The current exposure was based on the results of the dust measurements performed in the on going study and for subjects without a personal dust sample the exposure was derived from equivalent job tasks. The overall mean exposure to dust was estimated on the basis of a job-exposure matrix covering geometric mean values of all personal dust measurements collected for each specific job task. For subjects with mixed occupations within the dolomite industry, a weighted geometric mean exposure to dust was calculated taking the overall exposure to dust in each of these occupations into account. Subjects with occupations for which no exposure data were available were assigned exposure to dust concentrations by one of us (NPB) based on estimates derived from similar occupations or job tasks.

FIBRE ANALYSIS

The method used for fibre counting in this study was based on the current standard procedure in Sweden, ${ }^{28}$ which is similar to other international fibre counting methods. ${ }^{29-31}$ A respirable fibre was defined as a fibre longer than $5 \mu \mathrm{m}$ with a diameter less than $3 \mu \mathrm{m}$ and an aspect ratio of 5:1 or more. However, an aspect ratio of $3: 1$ or more is often used internationally and fibres were also counted on the basis of this definition.

Before fibre counting, the high content of dolomite particles on the filters was eliminated by acid leaching with $50 \mathrm{ml} 1.5 \mathrm{M} \mathrm{HCl}$. The filters were then washed with $50-100 \mathrm{ml}$ distilled water. The acid solution as well as the water was slowly rinsed through the filters while placed in a special filtration holder. To separate other non-asbestos fibres and tremolite cleavage fragments from tremolite asbestos, the following optical characteristics of tremolite asbestos were used during fibre counting: a refractive index of a countable tremolite asbestos fibre of about 1.62, birefringence, a positive sign of elongation and parallel or almost parallel extinction $\left(<5^{\circ}\right)$ when viewed in the microscope. ${ }^{32}$

Cinnamaldehyde was substituted for the standard mounting procedure with acetonetriacetin. It has a refractive index of 1.62 and makes the cellulose nitrate filter transparent and attains a blue colour with a red to yellow halo to tremolite asbestos and other objects with the same refractive index. The filters were evaluated within 2 days of preparation.

The birefringence and other optical characteristics - for example, sign of elongation and angle of extinction of these blue fibres-were checked with polarising equipment in the microscope. Fibres with nearly parallel extinction but too thin to appear coloured were also classified as tremolite asbestos.

A Leitz Ortolux II POL-BK polarising microscope with phase contrast equipment and object magnification of $40 \times$ was used on line to a Macintosh computer as previously described..$^{33}$ The system has a Walton-Beckett eyepiece graticule for fibre counting both in the microscope and on the computer screen, and the microscope has a rotating stage, allowing evaluation of both the sign of elongation and the angle of extinction of the fibres.

STATISTICAL METHODS

The prevalence of respiratory symptoms, using the cut off value of three or more symptoms, was analysed with multiple logistic regression models. The analysis was performed with either overall mean exposure to dust or current exposure to dust as the main explanatory variable. Both exposure variables were categorised into three classes with cut offs at 5.0 and 10.0 $\mathrm{mg} / \mathrm{m}^{3}$ dust. Age and smoking habits were included as additional variables as they were considered potential confounders. We used three categories for smoking, non-smokers as reference category, and ex-smokers and smokers as two index groups. The effect variable for the logistic regression was expressed as an odds ratio with a $95 \%$ confidence interval $(95 \% \mathrm{CI})$.

Lung function was first analysed with statistical models where means (95\% CIs) for the deviation of observed spirometric values from predicted values were calculated for all subgroups, taking into account the exposure to dust variables as well as background characteristics such as sex, age, BMI, and duration of 
Table 4 Summary of historical and contemporary measurements of total dust (personal samples) and tremolite asbestos (stationary samples) 1969-96 at companies $A$ and $B$, respectively, by department and occupation

\begin{tabular}{|c|c|c|c|c|c|c|c|c|c|c|c|}
\hline \multicolumn{6}{|l|}{ Company $A$} & \multicolumn{6}{|l|}{ Company B } \\
\hline \multirow[b]{2}{*}{$\begin{array}{l}\text { Department/ } \\
\text { job task }\end{array}$} & \multicolumn{3}{|c|}{ Total dust } & \multicolumn{2}{|c|}{ Tremolite asbestos } & \multirow[b]{2}{*}{$\begin{array}{l}\text { Department/ } \\
\text { job task }\end{array}$} & \multicolumn{3}{|c|}{ Total dust } & \multicolumn{2}{|c|}{ Tremolite asbestos } \\
\hline & $n$ & $\begin{array}{l}G M \\
\left(m g / m^{3}\right)^{\star}\end{array}$ & $\begin{array}{l}\text { Range } \\
\left(\mathrm{mg} / \mathrm{m}^{3}\right)\end{array}$ & $n$ & $\begin{array}{l}\text { Maximum } \\
\text { (fibres/ } \\
\mathrm{ml})+\end{array}$ & & $n$ & $\begin{array}{l}G M \\
\left(m g / m^{3}\right)^{*}\end{array}$ & $\begin{array}{l}\text { Range } \\
\left(\mathrm{mg} / \mathrm{m}^{3}\right)\end{array}$ & $n$ & $\begin{array}{l}\text { Maximum } \\
\text { (fibres } / \mathrm{ml} \text { ) }\end{array}$ \\
\hline Underground mine: & & & & & & Open cast mine: & & & & & \\
\hline Drilling & 6 & 2.9 & $1.0-59$ & 2 & $<0.03$ & Drilling & 11 & 12.5 & $0.2-78$ & 1 & $<0.03$ \\
\hline Charging & 9 & 10.9 & $3.4-68$ & & - & Loading & 3 & 0.6 & $0.3-2.1$ & 1 & $<0.03$ \\
\hline Loading & 4 & 2.5 & $1.1-3.5$ & 1 & 0.06 & Lorry driving & 2 & 0.2 & $0.1-0.3$ & 1 & $<0.03$ \\
\hline Mixed & & 6.05 & & & - & & & & & & \\
\hline Mill: & & & & & & Mill: & & & & & \\
\hline Manual sorting & 18 & 20.4 & $2.8-56$ & 2 & 0.10 & Manual sorting & 6 & 11.8 & $1.9-55$ & 2 & 0.04 \\
\hline Crushing & 12 & 21.4 & $2.2-83$ & 1 & $<0.03$ & Crushing & 6 & 5.9 & $2.9-10$ & 1 & $<0.03$ \\
\hline Bagging & 32 & 20.7 & $2.5-136$ & 4 & 0.12 & Bagging & 9 & 21.7 & $5.0-55$ & 3 & 0.14 \\
\hline Truck driving & 2 & 1.0 & $0.7-1.5$ & 1 & $<0.03$ & Truck driving & 3 & 3.9 & $3.1-4.9$ & 1 & 0.05 \\
\hline Service & & $9.2 \ddagger$ & & & - & Service & & $6.0 \ddagger$ & & & - \\
\hline Mixed & & $18.3 \S$ & & & - & Mixed & & $10.1 \$$ & & & - \\
\hline Other & & $1.0 \ddagger$ & & & - & Other & 2 & 1.1 & $0.9-1.4$ & 1 & $<0.03$ \\
\hline Lime works: & & & & & & Lime works: & & & & & \\
\hline Mixing & 42 & 9.6 & $0.5-36$ & 3 & $<0.03$ & Mixing & 14 & 8.0 & $1.7-17$ & 3 & 0.03 \\
\hline Bagging & 21 & 13.2 & $2.9-72$ & 2 & 0.03 & Truck driving & 2 & 2.3 & $1.2-4.6$ & 1 & $<0.03$ \\
\hline Truck driving & 2 & 0.4 & $0.4-0.5$ & 1 & $<0.03$ & Mixed & & $5.7 \S$ & & & - \\
\hline Mixed & & $7.9 \$$ & & & - & Other & & $1.1 \ddagger$ & & & - \\
\hline Other & & $0.4 \ddagger$ & & & - & & & & & & \\
\hline Putty works: & & & & & & Putty works: & & & & & \\
\hline Mixing & 14 & 6.0 & $2.4-16$ & 5 & 0.03 & Mixing & 8 & 3.6 & $1.2-11$ & 4 & 0.03 \\
\hline Truck driving & 2 & 1.3 & $0.9-1.8$ & 1 & $<0.03$ & Truck driving & 2 & 0.9 & $0.7-1.2$ & 1 & $<0.03$ \\
\hline Mixed & & $4.6 \rrbracket$ & & & - & Mixed & & $2.7 \S$ & & & - \\
\hline Other & & $1.3 \ddagger$ & & & - & Other & & $1.1 \ddagger$ & & & - \\
\hline Total & 158 & & & 23 & & Total & 68 & & & 20 & \\
\hline
\end{tabular}

${ }^{\star}$ Geometric mean

†Maximum values; all samples collected in 1996; aspect ratio $\geqslant 5: 1$.

$\ddagger$ Estimate.

§Weighted geometric mean (for details, see text).

-No data.

employment. In a secondary analysis we used several multiple linear regression models where one of the exposure to dust variables, either overall mean exposure or current exposure, was analysed simultaneously for different categories of the background variables age, height, BMI, and smoking.

\section{Results}

EXPOSURE ASSESSMENT

Overall, $70 \%$ of the participants considered their current work environment as quite dusty or very dusty ( $68 \%$ at company A, $73 \%$ at company B). However, regular use of respirators was reported by very few subjects $(3 \%)$. Previous occupational or private exposure to asbestos was recognised by 32 subjects (25\%), three of whom reported both sources of exposure.

The compilation of historical exposure data for total dust yielded highly variable results depending on the type of activity or job task considered (table 4). A substantial variability over time was also noted for some jobs but clear trends were not found. Contemporary total dust measurements, however, generally showed lower concentrations (median $2.8 \mathrm{mg} / \mathrm{m}^{3}$; details not shown) than the historical dust samples. At both companies, the highest exposure concentrations were found in the milling department, notably during bagging, and in manual stone sorting. In other departments, bagging and mixing as well as various mining operations also generated high concentrations of exposure to dust - that is with a geometric mean of $10 \mathrm{mg} / \mathrm{m}^{3}$ or more. Besides certain processes involving mixing of dolomite with quartz rich sand, the silica content of the dust had been negligible (median $0.03 \mathrm{mg} / \mathrm{m}^{3}$; details not shown) as indicated from the historical measurements.

The concentrations of tremolite asbestos in the contemporary samples were very low, generally $(70 \%$ of samples from company A, $65 \%$ of samples from company B) below the limit of detection (0.03 fibres $/ \mathrm{ml})$. Somewhat higher concentrations, about 0.1 fibres $/ \mathrm{ml}$ with a maximum value of 0.14 fibres $/ \mathrm{ml}$ at company $\mathrm{B}$, were found during manual stone sorting and bagging of pure dolomite (table 4). In general, with more dust in the air the concentration of tremolite asbestos fibres tended to increase. The median length of the recorded respirable fibres was $10-15 \mu \mathrm{m}$ with a median aspect ratio of 11-15:1 for different work tasks-that is, somewhat thinner and shorter fibres than typical asbestos fibres. If a fibre aspect ratio of 3:1 or more was used instead of 5:1 or more, the increase in asbestos fibre concentrations was limited ( $6 \%$ on average).

\section{RESPIRATORY HEALTH SURVEY}

\section{Respiratory symptoms}

The distribution of symptoms was positively skewed with a median of zero (85 subjects). Twenty one workers reported one or two symptoms whereas three or more symptoms, suggesting chronic bronchitis, were acknowledged by $24(18 \%)$. This figure was similar to previous findings in welders $(17 \%)$ with a somewhat lower proportion of smokers, but considerably lower than that of swine producers (34\% for all ages and $29 \%$ in younger than 60 years). In the present study the most common symptoms were cough without phlegm and dyspnoea, indicating a low physical 
Table 5 Lung function (l) in dolomite workers by sex, age, body mass index, duration of employment, overall mean, and current dust exposure

\begin{tabular}{|c|c|c|c|c|c|}
\hline \multirow[b]{2}{*}{ Characteristic } & \multirow[b]{2}{*}{ No. } & \multicolumn{2}{|l|}{ Vital capacity } & \multicolumn{2}{|c|}{ Forced expiratory volume, 1 second } \\
\hline & & $\begin{array}{l}\text { Observed mean } \\
(S D)\end{array}$ & $\begin{array}{l}\text { Deviation from predicted } \\
\text { mean }(95 \% \mathrm{CI})\end{array}$ & $\begin{array}{l}\text { Observed mean } \\
(S D)\end{array}$ & $\begin{array}{l}\text { Deviation from predicted } \\
\text { mean }(95 \% \mathrm{CI})\end{array}$ \\
\hline \multicolumn{6}{|l|}{ Sex: } \\
\hline Male & 114 & $5.19(0.89)$ & $-0.23(-0.34$ to -0.12$)$ & $4.08(0.76)$ & $-0.05(-0.15$ to 0.05$)$ \\
\hline Female & 16 & $3.86(0.80)$ & $-0.17(-0.49$ to 0.14$)$ & $3.20(0.76)$ & $0.04(-0.23$ to 0.32$)$ \\
\hline Total & 130 & $5.02(0.98)$ & $-0.22(-0.33$ to -0.12$)$ & $3.98(0.82)$ & $-0.04(-0.13$ to 0.05$)$ \\
\hline \multicolumn{6}{|l|}{ Age (y): } \\
\hline $20-39$ & 56 & $5.53(0.82)$ & $-0.05(-0.21$ to 0.12$)$ & $4.49(0.62)$ & $0.10(-0.03$ to 0.23$)$ \\
\hline $40-49$ & 34 & $4.98(0.97)$ & $-0.24(-0.47$ to -0.02$)$ & $3.89(0.71)$ & $-0.06(-0.26$ to 0.13$)$ \\
\hline$\geqslant 50$ & 40 & $4.35(0.76)$ & $-0.45(-0.61$ to -0.30$)$ & $3.32(0.63)$ & $-0.21(-0.37$ to -0.06$)$ \\
\hline \multicolumn{6}{|c|}{ Body mass index: } \\
\hline $18.5-24.9$ & 41 & $5.10(1.11)$ & $-0.15(-0.36$ to 0.05$)$ & $3.98(0.90)$ & $-0.06(-0.24$ to 0.12$)$ \\
\hline $25.0-29.9$ & 62 & $5.15(0.97)$ & $-0.17(-0.33$ to -0.01$)$ & $4.10(0.81)$ & $0.03(-0.10$ to 0.17$)$ \\
\hline $30.0-34.9$ & 19 & $4.56(0.60)$ & $-0.47(-0.64$ to -0.29$)$ & $3.57(0.50)$ & $-0.24(-0.34$ to -0.13$)$ \\
\hline $35.0-39.9$ & 8 & $4.79(0.79)$ & $-0.43(-0.92$ to 0.06$)$ & $3.94(0.82)$ & $-0.02(-0.48$ to 0.44$)$ \\
\hline \multicolumn{6}{|c|}{ Duration of employment $(y)$ : } \\
\hline$<5$ & 17 & $5.34(1.18)$ & $-0.13(-0.46$ to 0.20$)$ & $4.20(0.94)$ & $-0.05(-0.30$ to 0.21$)$ \\
\hline $5-9$ & 46 & $5.11(0.85)$ & $-0.18(-0.36$ to 0.00$)$ & $4.11(0.74)$ & $0.00(-0.15$ to 0.15$)$ \\
\hline $10-19$ & 36 & $4.97(1.00)$ & $-0.25(-0.46$ to -0.05$)$ & $4.00(0.88)$ & $0.02(-0.16$ to 0.21$)$ \\
\hline$\geqslant 20$ & 31 & $4.78(0.99)$ & $-0.30(-0.53$ to -0.07$)$ & $3.63(0.69)$ & $-0.16(-0.36$ to 0.04$)$ \\
\hline \multicolumn{6}{|c|}{ Overall mean exposure to dust $\left(\mathrm{mg} / \mathrm{m}^{3}\right)$ : } \\
\hline$<5.0$ & 61 & $5.18(0.86)$ & $-0.15(-0.29$ to -0.01$)$ & $4.11(0.69)$ & $0.03(-0.10$ to 0.15$)$ \\
\hline $5.0-9.9$ & 35 & $4.93(1.09)$ & $-0.32(-0.55$ to -0.08$)$ & $3.93(0.89)$ & $-0.10(-0.28$ to 0.09$)$ \\
\hline & 34 & $4.83(1.04)$ & $-0.26(-0.48$ to -0.04$)$ & $3.78(0.91)$ & $-0.09(-0.29$ to 0.11$)$ \\
\hline \multicolumn{6}{|c|}{ Current exposure to dust $\left(\mathrm{mg} / \mathrm{m}^{3}\right)$ : } \\
\hline$<5.0$ & 94 & $5.11(0.90)$ & $-0.20(-0.32$ to -0.07$)$ & $4.07(0.74)$ & $-0.01(-0.12$ to 0.10$)$ \\
\hline $5.0-9.9$ & 32 & $4.82(1.21)$ & $-0.26(-0.48$ to -0.03$)$ & $3.77(0.99)$ & $-0.09(-0.28$ to 0.10$)$ \\
\hline$\geqslant 10.0$ & 4 & $4.52(0.49)$ & $-0.52(-1.30$ to 0.26$)$ & $3.42(0.62)$ & $-0.27(-1.22$ to 0.68$)$ \\
\hline
\end{tabular}

fitness, whereas symptoms such as wheezing and phlegm were less often reported. In the univariate analysis the mean number of symptoms were less than one in the two lowest exposure categories (overall mean exposure to dust $<5.0$ and $5.0-9.9 \mathrm{mg} / \mathrm{m}^{3}$, respectively) and 2.1 in the highest category $\left(\geqslant 10.0 \mathrm{mg} / \mathrm{m}^{3}\right)$. The number of symptoms was higher in smokers (mean 2.1 symptoms) than in never smokers (mean 0.7 symptoms) but did not increase with age. In the logistic regression of symptoms (dichotomised into less than three and three or more symptoms) with age and smoking, only smoking was significant, corresponding to an odds ratio of 4.0 (95\% CI 1.3 to 12.0$)$. The same analysis with smoking and overall mean exposure to dust (age not included due to collinearity with exposure) also yielded a significant association with smoking (odds ratio 2.4 for smokers $v$ non-smokers, 95\% CI 1.3 to 11.7). A non-significant association with symptoms, corresponding to an odds ratio of 2.6 ( $95 \%$ CI 0.8 to 7.0 ), was found in the highest exposure category.

\section{Spirometry}

In the primary analysis of lung function, the mean deviation of observed from expected VC was about 0.21 , somewhat higher in men than in the small group of female workers (table 5). By contrast, the mean observed $\mathrm{FEV}_{1}$ was close to that expected for both sexes. There was a close collinearity between age and duration of employment, and both variables showed an accelerating loss of VC with increasing number of years. Similar findings were also found for BMI. Dose-response relations were found between deviations of VC from predicted and the overall mean exposure to dust as well as the current exposure to dust where the highest nominal VC deficit of 0.521 was found in the $\geqslant 10 \mathrm{mg} / \mathrm{m}^{3}$ category of current exposure. This estimate, however, was quite unstable as it carried information from only four subjects.

Attempts were made to identify the relative influence of age, BMI, and various exposure estimates on the VC but extended multivariate analyses did not yield additional information.

\section{Chest radiography}

Three subjects did not participate in the radiological part of the study (two workers had left, one refused) and for one subject no films, initially considered normal, could be retrieved. Of the 126 radiographs available for the reassessment according to the ILO system, 121 films were classified as negative for pneumoconiosis. The observers agreed on two cases of pleural plaques and they disagreed on the remaining three films. In two of these, one observer each noted pleural plaques whereas the other observer did not. The last film was classified in ILO category $1 / 1$, indicating simple pneumoconiosis, by one observer and normal by the other.

Details of the two definite cases of pleural plaques (both men) recovered from the questionnaires showed that one subject had been employed for only 3 years in the carbonate rock industry, suggesting previous exposure to asbestos elsewhere. The other subject had worked for 22 years in the current business and denied previous occupational or private exposure to asbestos. Hence, a relation with tremolite asbestos or other sources of exposure to asbestos in the carbonate rock industry, as previously indicated, was considered possible.

In the two cases with discordant findings of pleural plaques, one subject had been employed in the trade for over 30 years and had a considerable exposure to dolomite dust. The second possible case of plaque had been exposed to dolomite dust only during the previous 7 years, and any association with 
exposure to asbestos within the dolomite industry was therefore unlikely. Finally, the subject with possible simple pneumoconiosis had been working for 19 years in the carbonate rock industry and his exposure to dust was considered heavy during the first 12 years.

\section{Discussion}

The occurrence of an airborne exposure to tremolite asbestos in carbonate rock mining and milling was confirmed in the present study, but current exposure concentrations were generally low or even very low. Despite differences in analytical methods, the results were largely in agreement with findings from Finland, ${ }^{2}$ where deposits of carbonate rock have been formed under similar geological conditions.

The low concentrations of tremolite asbestos generally found in the work environment of companies A and B may be attributed to both a low material content and the production process. Applying the same fibre definitions as above, transmission electron microscopy analysis of dolomite products from company B, commissioned by the company, showed some $0.2 \%-0.4 \%$ of tremolite fibres less than $3 \mu \mathrm{m}$ wide in bulk samples (G Burdett, personal communication, 1996). These results, however, included both tremolite asbestos and elongated cleavage fragments, and more accurate analyses of technical dolomite samples from both companies showed tremolite asbestos concentrations of less than $10^{-5} \%$ on a weight basis ( $\mathrm{P}$ Herskind and VH Madsen, personal communications, 1998). Also, manual stone sorting of raw dolomite was performed for technical and commercial reasons at both companies and would be expected to reduce the entry of visible tremolite, often found as a discolouring contaminant, from the downstream production process.

On the other hand, the method for fibre analysis may to some extent have affected the dust collected on the filters. The acid leaching procedure may have dissolved or split large non-respirable agglomerates into smaller fragments and some fibres that appear to be respirable on the filter after leaching might originally have been combined with dolomite or other leachable materials in larger non-respirable agglomerates. The outcome of such possible effects would be to inflate the tremolite asbestos fibre counts.

As no valid analytical method for tremolite asbestos in dolomite had been available before the current investigation there were no historical data on exposure to tremolite asbestos. However, it would be reasonable to assume a correlation between exposure to tremolite asbestos and general dust concentrations, and in earlier decades exposure to tremolite asbestos concentrations of, say, one order of magnitude higher than the current figures may have occurred at specific locations, notably in the bagging areas of the dolomite mills. Yet few workers have probably been exposed for any extensive period to such historical exposure concentrations of tremolite asbestos. Hence, exposure to tremolite asbestos does not seem to be or have been a major problem at these companies.

Given the relatively low exposure to tremolite asbestos, the low prevalence of radiological findings related to asbestos was not surprising. Among the 126 radiographs obtained during this investigation, only one case of pleural plaques unanimously agreed upon by the two observers could reasonably be associated with dolomite production. It was noted, however, that this subject was first employed at a time when asbestos was still possibly used as an additive to certain dolomite products and even for this subject the association with exposure to tremolite asbestos was unclear. With more sensitive radiological methods, notably computed tomography of the chest, additional cases of pneumoconiosis might have been detected. However, as opposed to the ILO algorithm for systematic reading of traditional chest radiographs there is as yet no internationally accepted method for evaluation of CT findings in epidemiological studies although such a system is clearly needed.

Although the exposure to tremolite asbestos in this study was low and the health effects of this exposure, if any, were limited, the general exposure to dolomite dust, albeit reduced over time, had been impressive. As silica concentrations were also very low, any respiratory effects related to dust would probably be associated with dolomite dust. The level of complaints about the general exposure to dust among the workers was also high, indicating a need for further dust control measures as well as a reduction of smoking. The prevalence of respiratory symptoms suggestive of chronic bronchitis was of a magnitude previously found in welders of similar age but with fewer active smokers. However, the precision of the analysis of respiratory symptoms was hampered by the lack of a good reference material.

After age was taken into account, there was a gradual reduction of respiratory function, notably the VC, with duration of employment, and overall mean dust, as well as with current exposure to dust. The BMI was also associated with reduced lung function, suggesting an important contribution of increasing weight to the reduction in VC. These findings were not consistent throughout but our attempts to gain further insight into the causes of these deviations by multiple regression models only confirmed that this group of workers had a significant reduction of the VC compared with the reference values. Whether this difference should be attributed to the work environment or other factors, BMI for instance, could not be ascertained with the present data set. Indeed, a control group of unexposed workers would have improved the analysis, but such an extended design was beyond the scope of the study.

Over two thirds of the current study group considered their working environment as dusty or very dusty and people with sensitive airways would therefore be expected to find it difficult to work in many sectors of the trade. The magnitude of any such a selection effect on health was not possible to estimate in the present 
study, but it was noted that the mean $\mathrm{FEV}_{1}$ was close to expected values for both sexes, suggesting a low prevalence of study subjects with hyperreactive airways.

The overall results of the current study may be regarded as fairly consistent with previous findings of workers exposed to other nonfibrogenic minerals and inorganic dusts. ${ }^{1}$ From a more general perspective, however, it should be noted that the biological activity of tremolite asbestos is quite variable from one deposit to another, ${ }^{35}$ and the results obtained in this study may not be valid for carbonate rock workers elsewhere. In conclusion, exposure to tremolite asbestos was shown to occur at the companies involved in this investigation but the exposure concentrations were low and the exposure does not seem to constitute a major health hazard, either for risk of pneumoconiosis or impaired lung function. The limited size of the study as well as the geological characteristics of the current dolomite deposits do, however, suggest cautious inference to other populations of dolomite workers and further studies of exposure to tremolite asbestos in carbonate rock mining and milling are warranted.

We are indebted to several professionals for their assistance: professor Staffan Krantz and Dr Lars Winström, respectively, provided analytical and radiological expertise; Anette Magnus-
son, Birgit Wiberg-Olsson, Birgitta Linder, and Krister Berg son, Birgit Wiberg-Olsson, Birgitta Linder, and Krister Berg assisted during the epidemiological field work; Sibylla Robert-
son performed the total dust analyses, Ing-Liss Bryngelsson son performed the total dust analyses, Ing-Liss Bryngelsson
managed the data files; technical support was obtained from managed the data files; technical support was obtained from
Anette Holm, Ann-Charlotte Norr, and Maria Brånn. The Anette Holm, Ann-Charlotte Norr, and Maria Brånn. The
study was sponsored by companies A and B. Financial support was also received from the Orebro County Council Research Committee (grant No 232/97)

1 Parkes WR. Non-fibrogenic (inert) minerals and pneumoconiosis. In: Parkes WR, ed. Occupational lung disorders, 3rd ed. Oxford: Butterworth-Heinemann 1994:253-84

2 Junttila S, Tossavainen A, Hartikainen T, et al. Airborne mineral fibers and quartz dust in precambrian metamorphic limestone and dolomite mines in Finland. Appl Occup Environ Hyg 1996;11:1075-80.

3 Anttila S, Sutinen S, Pääkkö P, et al. Rheumatoid pneumoconiosis in a dolomite worker: a light and electron microscopic, and $x$ ray microanalytic study. $\mathrm{Br} \mathcal{F}$ Dis Chest 1984;78:195-200.

4 Yazicioglu S, Ilacayto R, Balci K, et al. Pleural calcification, pleural mesothelioma and bronchial cancers caused by tremolite dust. Thorax 1980;35:564-9.

5 tremolite dust. Thorax 1980;35:564-9. Saratzis N, et al.

Metsovo lung: pleural calcification and restrictive lung Metsovo lung: pleural calcification and restrictive lung function in northwestern Greece. Environmental exposur

6 Baris YI, Artvinli M, Sahin AA, et al. Non-occupational asbestos related chest diseases in a small Anatolian village. Br F Ind Med 1988;45:841-2.

7 Constantopoulos SH, Theodoracopoulos P, Dascalopoulos $\mathrm{G}$, et al. Metsovo lung outside Metsovo. Endemic pleural calcifications in the ophiolite belts of Greece. Chest 1991;99:1158-61.

8 Luce D, Bugel I, Goldberg P, et al. Environmental exposure to tremolite and respiratory cancer in Caledonia: a case-control study. Am f Epidemiol 2000;151:259-65.

9 Voisin C, Marin I, Brochard P, et al. Environmental airborne tremolite asbestos pollution and pleural plaques in Afghanistan. Chest 1994;106:974-6.

10 Metintas M, Özdemir N, Hillerdal G, et al. Environmental asbestos exposure and malignant pleural mesothelioma. Respir Med 1999;93:349-55.

11 Amandus HE, Wheeler R, Armstrong BG, et al. Mortality of vermiculite miners exposed to tremolite. Ann Occup Hyg 1988;32(suppl 1):459-65.
12 Armstrong BG, McDonald JC, Sébastien P, et al. Radiological changes in vermiculite workers exposed to tremolite. Ann Occup Hyg 1988;32 (suppl 1):469-74.

13 McDonald JC, McDonald AD. Chrysotile, tremolite and carcinogenicity. Ann Occup Hyg 1997;41:699-705.

14 McDonald JC, McDonald AD, Hughes JM. Chrysotile, tremolite and fibrogenicity. Ann Occup Hyg 1999;43:43942 .

15 Rönnegård N. Lungröntgenfynd och asbestexposition bland mellansvenska gruvarbetare (Pulmonary $x$ ray findings and asbestos exposure in miners from central Sweden). Solna: Arbetarskyddsstyrelsen 1985:17. (Projekt AD 238/83. In Swedish.)

16 Albin M. Asbestpleurit av sandspackel? En fallbeskrivning (Asbestos pleuritis from sand putty? A case report). Bulletin frän Yrkesmedicinska kliniken i Lund 1990;1:2. (In Swedish.)

17 Tell I, Svensson G. Pleuraplaque hos kyrkomålare (Pleural plaques in a church painter). Bulletin från Yrkes- och miljöplaques in a church painter). Bulletin från Yrkes-
medicinska kliniken $i$ Lund 1994;4:7. (In Swedish.)

18 World Health Organization. 7.2.1 Screening for interventions. In: Physical status: the use and interpretation of anthropometry. Report of a WHO Expert Committee. Geneva: World Health Organization, 1995:329-30. (WHO Technical Report Series 854.)

19 Fletcher CM, Peto R, Tingker C, et al. The natural history of chronic bronchitis and emphysema. Oxford: Oxford University Press, 1976.

20 Ohlson CG, Hogstedt C, Kiviloog J, et al. Validering av frågeformulär för luftvägssymtom (Validation of questionnaires on airway symptoms). Arbete och Hälsa 1984:27:34. (In Swedish, English summary.)

21 Ohlson CG, Hogstedt C. The MRC questionnaire on symptoms of bronchitis. A comparison with medical diagnoses and lung function. Ann Occup Hyg 1988;32(suppl 1):539-43.

22 Wilhelmsson J, Bryngelsson IL, Ohlson CG. Respiratory symptoms among Swedish swine producers. Am $\mathcal{F}$ Ind Med 1989;15:311-8

23 American Thoracic Society. Standardization of spirometry: 1987 update. Am Rev Respir Dis 1987;136:1285-98.

24 Hedenström H, Malmberg P, Agarwal K. Reference values for lung function tests in females. Regression equations with smoking variables. Bull Eur Physiopathol Respir 1985;21:551-7.

25 Hedenström H, Malmberg P, Fridriksson HV. Reference values for lung function in men: regression equations with smoking variables. Upsala f Med Sci 1986;91:299-310.

26 International Labour Office. Guidelines for the use of ILO international classification of radiographs of pneumoconioses. Occupational Safety and Health. Geneva: International Labour Office, 1980. (Series No 22 (Rev 80))

27 Eller PM, Cassinelli ME, eds. National Institute of Occupational Safety and Health. Particulates not otherwise regulated, total: method 0500. NIOSH manual of analytical methods, 4 th total: method 05. United States Dept of Health and Human Services, 1994:3. (DHHS Publ No 94-113.)

28 Standardiseringskommissionen i Sverige. Luftundersökningar: Arbetsplatsluft: Räknekriterier för asbestfibrer (Air investigations: workplace air: counting criteria for asbestos fibres). Stockholm: SIS, 1981:11. ( Svensk Standard SS 02 84 18. In Swedish.)

29 Asbestos International Association. Reference method for the determination of airborne asbestos fibre concentration at workplaces by light microscopy (membrane filter method). AIA recommended technical method No 1, 2nd reprint. London: AIA, 1988:13

30 Eller PM, Cassinelli ME, eds. National Institute of Occupational Safety and Health. Asbestos and other fibres by PCM: method 7400. NIOSH manual of analytical methods, 4th ed.Cincinnati: US Dept of Health and Human Services, 1989:15. (DHHS Publ No 94-113.)

31 Health and Safety Executive. Asbestos fibres in air: light microscope methods for use with the control of asbestos at work regulascope methods for use with the control of asbestos at work regulations. Methods for the determination of hazardous substanc

32 Burdett G. Identification of asbestos in bulk materials by polarised light microscopy (PLM). Sheffield: Health and Safety Laboratory, 1996. (Final report: EU-contract MAT1CT93-0003.)

33 Lundgren L, Lundström S, Laszlo I, et al. Modern fibre counting: a technique with the phase-contrast microscope on-line to a Macintosh computer. Ann Occup Hyg 1995;39: 455-67.

34 Lundgren L, Lundström S, Sundström G, et al. A quantitative method using a light microscope on-line to a Macintosh computer for the analysis of tremolite fibres in dolomite. Ann Occup Hyg 1996;40:197-209.

35 Davis JMG, Addison J, McIntosch C, et al. Variations in the carcinogenicity of tremolite dust samples of differing morphology. Ann N Y Acad Sci 1991;643:473-90. 